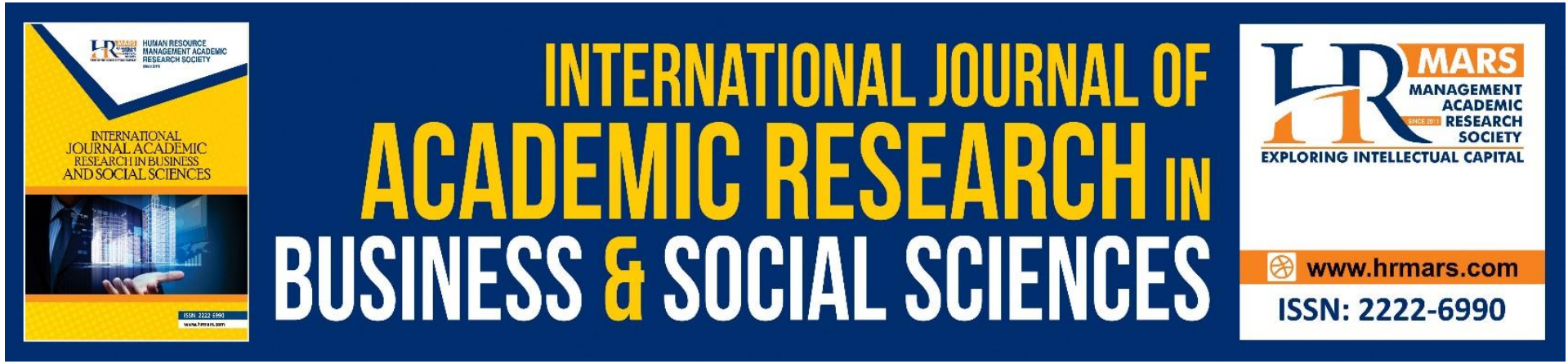

\title{
Instagram Interactive Face Filter To Motivate Speaking Skill Among Year 5 ESL Learners in Rural Sabah: Pupils' Perception
}

\section{Nurzawanah Rohaizat, Ang Fong Nie, Melor Md Yunus}

To Link this Article: http://dx.doi.org/10.6007/IJARBSS/v11-i7/10401

DOI:10.6007/IJARBSS/v11-i7/10401

Received: 16 May 2021, Revised: 20 June 2021, Accepted: 05 July 2021

Published Online: 26 July 2021

In-Text Citation: (Rohaizat et al., 2021)

To Cite this Article: Rohaizat, N., Ang, F. N., \& Yunus, M. M. (2021). Instagram Interactive Face Filter To Motivate Speaking Skill Among Year 5 ESL Learners in Rural Sabah: Pupils' Perception. International Journal of Academic Research in Business and Social Sciences, 11(7), 1286-1296.

Copyright: (c) 2021 The Author(s)

Published by Human Resource Management Academic Research Society (www.hrmars.com)

This article is published under the Creative Commons Attribution (CC BY 4.0) license. Anyone may reproduce, distribute, translate and create derivative works of this article (for both commercial and non-commercial purposes), subject to full attribution to the original publication and authors. The full terms of this license may be seen at: http://creativecommons.org/licences/by/4.0/legalcode

Vol. 11, No. 7, 2021, Pg. 1286 - 1296

Full Terms \& Conditions of access and use can be found at http://hrmars.com/index.php/pages/detail/publication-ethics 


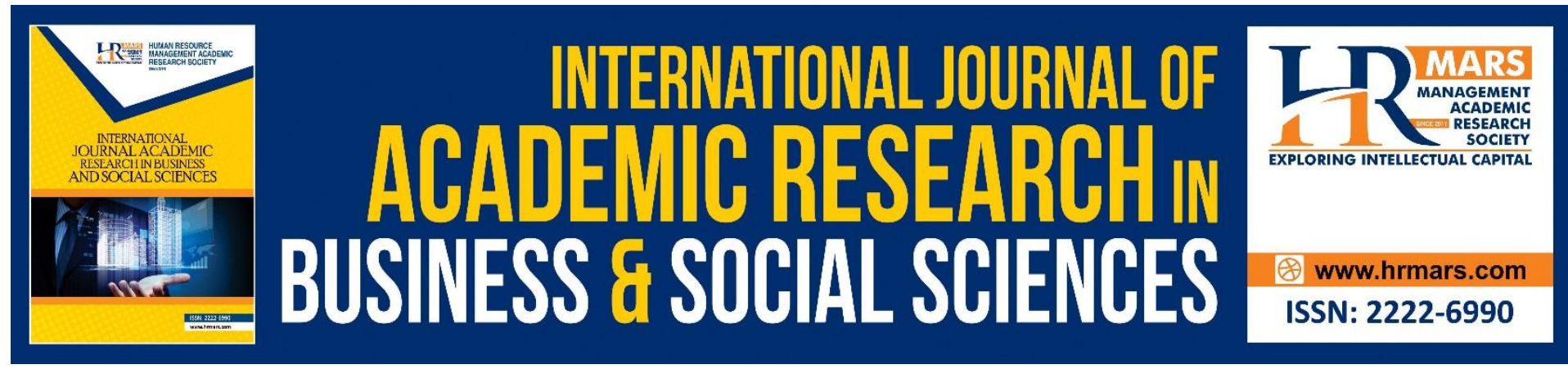

\title{
Instagram Interactive Face Filter To Motivate Speaking Skill Among Year 5 ESL Learners in Rural Sabah: Pupils' Perception
}

\author{
Nurzawanah Rohaizatt, ${ }^{1,3}$ Ang Fong $\mathrm{Nie}^{2,3}$, Melor Md Yunus ${ }^{3}$ \\ Faculty of Education, Universiti Kebangsaan Malaysia, 43600 Bangi, Malaysia \\ Email: ${ }^{1}$ wanah.rohaizat@gmail.com, 2angfongnie@gmail.com, ${ }^{3}$ melor@ukm.edu.my
}

\begin{abstract}
Recently, many students globally have embraced social media to facilitate learning. This study investigates the perception of students in using Instagram interactive face filters to enhance their speaking skills. The study is significant in identifying main areas in online learning and helps to understand the importance of using technology in learning. By researching how pupils perceive the use of interactive face filters in online learning, the study indicates that there are improved learning outcomes. Teachers, students, and institutions can use the present study to incorporate interactive online learning. The research uses a systematic method to gather, interpret, and draw conclusions of the research data; a quantitative survey method to collect data. The participants comprised 30 of the year five pupils of mixed levels from a Chinese school in rural Sabah. Data was collected online using Google Form, which comprised the questionnaire that participants filled. Regarding perception of students on using Instagram $100 \%$ of the respondents agreed that the application helps them in language learning and the necessity of it in learning speaking skills. Also, $80 \%$ of the respondents strongly agree that using Instagram is more enjoyable than regular speaking activity and the other $20 \%$ agree with the statement. These findings supported the TAM model, which suggested that pupils will be more attracted to incorporate new technology in their learning. The result also found that pupils are having fun and are more relaxed in speaking the English language while trying out the filters, thus motivating them to speak English more confidently. Education stakeholders should perform broader research on the topic to ensure more reliable findings. Since the current research was drawn from only 30 participants, there is a need to acquire data that can be used in a larger spectrum.
\end{abstract}

Keywords: Social Media, Online Learning, Instagram, Face Filter, Motivate

\section{Introduction}

Social media has become a common e-learning platform among students. One of the most popular features on social media is the face filter effect that incorporates Augmented Reality technology. Various studies have found that learning while using technologies such as computers and smartphones are effective in improving student's engagement and active participation in classrooms (Johns, 2015; Robertson, 2019). 
In this study, the Instagram interactive face filter is used in assisting the students to learn English more casually and enjoyably while being on social media. Instagram filters have been used as a fun way to interact with other people and to attract others to follow their Instagram account. The various elements provided in Instagram filters such as its engaging elements have helped to attract students' attention in using Instagram filters as part of the learning platform. Other than ensuring that students will be more engaged in their learning, the use of Instagram filters also helps to ensure that students will always practice their speaking skills outside the classroom. This is especially useful during this time of the Covid-19 pandemic where the teaching and learning still take place. Using Instagram filters to train students' speaking skills help to motivate students to speak and even train their speaking skill in English. The theory involved in this study is Stephen Krashen Second Language Acquisition Theory. This particular theory consists of 5 hypotheses in which the fourth hypothesis, which is the Affective filter hypothesis, is very much the main focus of this study. The research model proposed in this study is based on the Technology Acceptance Model (TAM) which suggests students will be more accepting to learn through new technology in their learning and it will help to improve their performance in their study. The TAM model proposed that the use of correct technology in teaching and learning will have a direct effect on students' motivation and intention in learning. The aim of the study is to investigate students' perception in using Instagram interactive face filters to enhance their speaking skills. This study also aims to explore whether students will be motivated to learn speaking skills through Instagram in learning via interactive face filters. This study intends to test the feasibility of this technique through an online survey conducted on Google Forms application which adapts the quantitative method of research.

\section{Literature Review}

Today, the conventional method of teaching and learning has been incorporated and gradually replaced by virtual teaching and learning environments. Therefore, an integration of mobile and technology into language education has become an everyday phenomenon (Zaki and Yunus, 2015). Social media platforms such as Twitter, Facebook, and Instagram are popular especially among young generations, specifically the students as they offer a variety of features that help engage students' attention. Some researchers defined social media as online platform sites that are based on user participation and user - generated content (Obar and Wildman, 2015). AlQahtani (2018) stated that there are many applications or sites of social media that are normally used by higher learning institutions such as Facebook, WhatsApp, Twitter, and LinkedIn and the use of social media influences the way they search, manage and use of information. Chen (2011) in Yen, Hou, and Chang (2015) found that interaction with computers provides a less intimidating and more comfortable situation than the interaction with humans. Lin, Warschauer, and Blake (2016) in Sun et al. (2017) reviewed thousands of users' opinions of a leading language learning social network site named Livemocha and discovered that majority of the users felt more motivated, confident, and comfortable texting online than in person after using Livemocha.

Due to its popularity among users of all ages and suitability and possible chance to be a learning tool. Some of the educators around the world have taken the initiative to use it as one of their e-learning platforms. Hence, making it one of the most popular platforms that students use to share, gain, and even communicate on things related to their learning. Manca and Ranieri (2013) stated that one of the most powerful teaching and learning tools are the 
social media platforms due to their nature of openness, interactivity, and sociability. This statement is supported by Vivakaran and Neelamalar (2018) claiming that the social media platforms used as learning tools were able to replace the traditional teaching and learning method as they enable learners to create, share and receive user-generated content virtually through their interactive features. More importantly, social media platforms create enjoyable and stress-free learning spaces tackled by educators to turn students' social media enthusiasm into a learning opportunity (McCarroll \& Curran, 2013).

\section{Theory and Model}

The theory involved in this innovative study is related to Stephen Krashen Second Language Acquisition Theory which includes five types of hypotheses. However, this study will only be focusing on the fourth hypothesis which is the Affective Filter hypothesis. Based on the Affective Filter hypothesis, students will be more willing, motivated, and encouraged to speak in English when they have low affective filters. Krashen (1981) stated that low affective filters involve the condition where pupils have high motivation, a positive attitude, high selfconfidence, and low anxiety which is necessary for language acquisition to take place. Handayani (2016) stated that using Instagram to encourage speaking skills is one of the best methods to increase communication skills and provide a 'back door' for shy learners. Thus, this method is suitable to apply to pupils in rural Sabah as they are having limited exposure toward speaking skills which cause them to be unable to brave themselves to speak and thus causing them to have high affective filters when learning speaking skills in the classroom using normal conventional teaching and learning methods. Jalaludin, Awal, and Bakar (2009) also found that the uncomfortable living environment makes it harder for the pupils to develop their speaking skills. Fortunately, studies conducted by Mat \& Yunus (2014) suggested that when pupils' extrinsic factors are fulfilled, they will be motivated and have positive attitudes toward English learning. Hence, supporting Instagram interactive face filter can be the extrinsic factor to motivate students in developing and improving their speaking skills. Instagram helps to produce low affective filters as students can practice and recreationally learn speaking skills. This is because interactive face filters can be accessed using mobile phones with a good internet connection and pupils can access and try the innovative interactive face filters anywhere and anytime that they want. It can be conducted outside the normal classroom and avoid the stress that students often feel when the teaching and learning of speaking skills take place in a formal conventional classroom. Moreover, the interactive face filters also offered a recreational way of learning speaking skills as they are learning to speak while trying out the filters on Instagram. The use of Instagram interactive face filters will also motivate the students in rural Sabah as even though they are used and known about social media platforms, they were rarely exposed to the use of it as part of the teaching and learning tools. Thus, they will be more accepting of using the interactive face filter in learning speaking skills. The benefits of using the features of Instagram interactive face filters have been supported by the study conducted by Azlan, Zakaria, and Yunus (2019) which find that the integration of Instagram in the learning of language have a good impact in enhancing students' self-confidence to express their ideas and motivate them to become fluent English speakers.

\section{Speaking Skills}

Speaking skills are one of the four main skills in the English language. It is also one of the important skills in language learning. (Parveen, 2016). Speaking skills are also involved in 
one's ability to express ideas and opinions verbally (Pratiwi, 2013). However, it's not easy to teach speaking skills to students as it's not only needed for teachers to find and take the best teaching and learning approaches, methods, and strategies to encourage and even motivate students in developing their speaking skills, the students need to be motivated and interested with learning and developing speaking skills too. Therefore, this research of using Instagram interactive face filters has been conducted to motivate students to enhance their speaking skills using interactive face filters. The social media platform used in this research is by Instagram. A lot of previous studies have been conducted to find out whether social media platforms can be beneficial in enhancing and developing students' speaking skills. For instance, Yen et al (2015) in a case study in Taiwan has found out that Facebook and Skype helped to improve the students' writing and speaking skills. Sun and Yang (2015) in Sun et al. (2017) also had proven that using YouTube and Facebook helped to enhance speaking and pronunciation and at the same time also improved their confidence in speaking. Based on the previous research and practical observations made by Khan et al (2016) have also shown that many active users of social media applications have a positive outcome on English learning proficiency at the university level.

\section{Motivation}

In Sabah state, the students especially those who come from rural areas are having trouble speaking in English due to their lack of motivation in developing and learning the skills. Motivation is generally divided into two which are intrinsic factors and extrinsic factors. Both factors stimulate the pupils' interest and commitment to developing speaking skills. Al-Eisa et al. (2016) stated that intrinsic factors are those done for satisfaction one gains from engaging in the activity itself. Whereas extrinsic factors refer to the need for achievement to get certain rewards (Pittman \& Bogiano, 1992; Mat \& Yunus (2014).

The pupils in rural Sabah are having low motivation both intrinsically and extrinsically, this is caused by their background, where most of the rural pupils did not come from an educated background and the parents are satisfied with their children's limited ability in mastering the four skills involved in the English language. Thus, they don't feel the need to improve themselves. Moreover, students from rural areas have limited exposure to learning to speak the language as most of them will only depend on the teachers in the schools to speak and teach them speaking skills. In other words, those in rural areas do not have sufficient exposure to practice speaking skills. Add in lack of support from their surroundings, this causes them to still have poor speaking skills despite learning the language since pre-school.

\section{Instagram Interactive Face Filters}

Instagram is a mobile application that allows users to capture and share images and videos with followers. Based on the data released by Sprout Socialin 2020, it is reported that Instagram is one of the fastest-growing applications with a variety of features accessible to attract the attention of social media users especially among younger generations. Due to its rapidness, popularity, and interesting offered features, it is also one of the social media platforms that can be innovated as one of the e-learning mediums. Instagram can be a powerful teaching tool in encouraging speaking activity among pupils in rural Sabah. This is supported by a study conducted by Mansor \& Abd (2017), in which they found out that Instagram is an effective tool used to enhance students' communication skills through taskrelated activities. It parallels with the study conducted by Lunden (2020) as well as 
Simatupang and Salam (2015), based on the study conducted that concluded that Instagram helped in the process of learning. This is due to it being one of the popular social media platforms and the interactive face filters feature that is provided as one of the features.

Based on the Internet Users Survey conducted by the Malaysian Communications and Multimedia Commission (MCMC) in 2017, Instagram at $56.1 \%$ is the second-highest Social Networking Sites preferences among Malaysian after Facebook. Moreover, according to a study by Sprout Social in 2020, Instagram is widely used from generation X to generation Alpha. Hence, this could be an opportunity to optimise the potentials of using technology in developing and motivating students to enhance their speaking skills. Instagram is chosen to be a part of teaching and learning tools due to its interactive face filters which can motivate and encourage pupils to develop and learn their speaking skills. This supported by Pratiwi (2019) in her research in which she mentioned that she was using Instagram to support her pupils' ability in speaking skills as 'Instagram is popular and among the favourite by most social media users'. The use of interactive face filters via Instagram application to motivate pupils in rural Sabah speaking skills also supported by Stephen Krashen Second Language Acquisition Theory and the Technological Acceptance (TAM) Model.

\section{Methodology}

This part will discuss thoroughly on the methodology used in this study which will be the research design, participants, research instruments and data collection procedures. To get an insight and feedback on pupils' perception regarding the use of Instagram in motivating them in practicing their speaking skill, this study adapted the survey quantitative method. The participants of this study comprise 30 of the Year 5 pupils of mixed levels from a Chinese school in rural areas of Sabah who were willing to try out the innovative new learning tool which is the Instagram interactive face filter. The data was collected through an online survey by using the Google Form application to distribute the questionnaire to the participants who had used the interactive face filters on Instagram. Questions from a previous study was meticulously examined before being adapted to accommodate the questionnaire objectives. Primarily, the study is based on the survey instrument employed by Yunus et al. (2019) in their study 'Kahoot!: Engaging and Active Learning Environment in ESL Writing Classrooms'. The questionnaire consists of 13 questions with 2 different sections focusing on their familiarity with the Instagram application and their experience in participating in the activity on the platform. The response for each item will be measured using the 5 -point Likert Scale $(1=$ strongly disagree, 2 = disagree, $3=$ neutral, $4=$ agree, $5=$ strongly agree). The questionnaire was conducted in English language and Malay language to ensure pupils' understanding of the content. All participants were reminded to answer the questionnaire in full honesty. The questionnaire was developed by using the Google Form application and the link was distributed to the 30 participants via WhatsApp. All respondents received the consent from the parents and guardian to answer the questionnaire.

\section{Findings and Discussion}

The collected data from the survey are from 30 participants who were involved in using the interactive face filters on Instagram. The questionnaire is divided into two sections which are significant to the research objective. 


\section{Pupils' Perception Towards Instagram}

The items in Section A were constructed to find out pupils' familiarity and perception towards the use of Instagram in learning English speaking skill. The result of the 3 questions is shown in Table 1.

Table 1: Pupils Perception towards Instagram

\begin{tabular}{lc|c}
\hline \multicolumn{1}{c}{ Questions } & \multicolumn{2}{c}{ Answer (\%) } \\
\cline { 2 - 3 } & Yes & No \\
\hline $\begin{array}{l}\text { Have you used Instagram in English } \\
\text { lessons? }\end{array}$ & 83.3 & 16.7 \\
\hline $\begin{array}{l}\text { Do you feel that Instagram helps in } \\
\text { your language learning? }\end{array}$ & 100 & 0 \\
\hline $\begin{array}{l}\text { Do you feel it is necessary to use } \\
\text { Instagram in learning speaking skills? }\end{array}$ & 100 & 0 \\
\hline
\end{tabular}

Based on Table 1, the data shows that $83.3 \%$ have the experience in using the Instagram application in their English lesson and only 16.7\% did not have the experience in using the application in learning English. 100\% of the respondents agree that the application helps them in language learning as well as the necessity of it in learning speaking skills. Therefore, the finding is in coordination with the finding of Devi at al. (2020) that there is a strong or successful response to students' impressions of the use of Instagram in learning English speaking skills. Instagram is perceived as a tool that will assist pupils in enhancing their English-speaking ability.

Pupils' Motivation Towards Enhancing Speaking Skills Through Instagram In Section B, the 10 items in the questionnaire focuses on their motivation to practice speaking skills while using Instagram. 
Table 2: Pupils Motivation towards Enhancing Speaking Skills Through Instagram

\begin{tabular}{l|c|c|c|c|c}
\hline \multicolumn{1}{c|}{ Questions } & \multicolumn{4}{c}{ Answers (\%) } \\
\cline { 2 - 5 } & 1 & 2 & 3 & 4 \\
\hline $\begin{array}{l}\text { I think activity on Instagram is more } \\
\text { interesting compared to normal speaking } \\
\text { activity }\end{array}$ & 0 & 0 & 0 & 20 & 80 \\
\hline $\begin{array}{l}\text { I think Instagram makes me participate } \\
\text { actively in speaking activity }\end{array}$ & 0 & 3.3 & 6.7 & 30 & 60 \\
\hline $\begin{array}{l}\text { I feel burdened whenever I need to complete } \\
\text { the task on Instagram }\end{array}$ & 46.7 & 30 & 16.7 & 6.7 & 0 \\
\hline $\begin{array}{l}\text { I feel like it is more convenient for me to } \\
\text { complete an online task compared to in a } \\
\text { normal classroom. }\end{array}$ & 0 & 6.7 & 0 & 16.7 & 76.7 \\
\hline $\begin{array}{l}\text { I am more engaged in the speaking activity } \\
\text { through Instagram. }\end{array}$ & 0 & 3.3 & 0 & 26.7 & 70 \\
\hline $\begin{array}{l}\text { I feel the need to participate in the activity } \\
\text { whenever my teacher posts a task on } \\
\text { Instagram. }\end{array}$ & 0 & 0 & 10 & 36.7 & 53.3 \\
\hline $\begin{array}{l}\text { I usually just complete the task without giving } \\
\text { much effort. }\end{array}$ & 16.7 & 23.3 & 20 & 6.7 & 33.3 \\
\hline $\begin{array}{l}\text { I feel happy and motivated to complete the } \\
\text { task on Instagram }\end{array}$ & 0 & 0 & 0 & 33.3 & 66.7 \\
\hline $\begin{array}{l}\text { Whenever I make a mistake, I will try to } \\
\text { correct myself. }\end{array}$ & 0 & 0 & 16.7 & 40 & 43.3 \\
\hline $\begin{array}{l}\text { I feel excited whenever I see my video on } \\
\text { Instagram. }\end{array}$ & 0 & 0 & 13.3 & 36.7 & 50 \\
\hline
\end{tabular}

As seen on Table 2, the highest percentage can be seen in item 1 whereby $80 \%$ of the respondents strongly agree that using Instagram is more interesting compared to normal speaking activity and the other $20 \%$ agree with the statement. In item 3, $46.7 \%$ and $30 \%$ strongly disagree and disagree respectively that Instagram makes them feel burdened whenever they need to complete the task on Instagram $16.7 \%$ remains neutral and $6.7 \%$ disagree with it. Then, based on the statement in item 5, 21 respondents (70\%) feel that they are more engaged in the speaking activity on Instagram and 8 respondents $(26.7 \%)$ agree with the item. 1 respondent (3.3\%) however disagrees with the statement. The result shows a similarity with a previous study by Devi, Virginia, and Auli (2020) that Instagram is an interesting medium to practice English especially outside of the classroom.

$66.7 \%$ which is represented by 20 respondents strongly agree with item 8 that they feel happy and motivated to complete the task on Instagram and the other 10 respondents (33.3\%) agree with it. The result for item 10 shows that $50 \%$ and $36.7 \%$ of the respondents strongly agree and agree respectively that they feel excited whenever they see their videos on the Instagram story. The remaining $13.3 \%$ voted neutral for this item. This finding is in parallel with Pujiati at al (2019) that Instagram plays a critical role in supporting students in increasing their motivation to learn English and, as a result, their English competency, and skills.

These findings supported the TAM model which suggested that pupils will be more attracted 
to try out new technology in their learning. The finding also found out that pupils are having fun and more relaxed in speaking the English language while trying out the filters. Thus, motivating them to speak more English more confidently. Other than that, the innovation of the Instagram face filter that incorporates English learning elements such as speaking skills helps to eliminate the pupils' mental obstacles such as their low self-esteem that causes them to be a burden in speaking in English. This is due to the low affective filter provided by the Instagram face filter which provided pupils with a recreational learning environment that helps to lower down the filters affecting them to learn as suggested in the Krashen Affective filter hypothesis.

\section{Conclusion}

Speaking skill is one of the most difficult skills to be mastered by the students due to a lot of factors such as shyness and low self-esteem. However, by integrating the activities through social media and presenting it in a real-life setting, pupils can give active participation and commitment. The content of the interactive face filters on Instagram which was initially built for entertainment purposes can be transformed into something more educational to meet the students' interests. Therefore, it allows them to experience and generate ideas on relevant content and enjoy the learning session. This is an effective tool that offers teachers a great opportunity to shift from traditional speaking skill activities to the 21st century learning styles and an easier way of communication especially during the period of online learning. Education stakeholders should perform broader research on the topic to ensure more reliable findings. Since the current research was drawn from only 30 participants, there is a need to acquire data that can be used in a larger spectrum

\section{Conflict of Interest}

The authors declare no conflict of interest.

\section{References}

Al-Eisa, E., Al-Rushud, A., Alghadir, A., Anwer, S., Al-Harbi, B., Al-Sughaier, N., Al-Yoseef, N., Al-Otaibi, R., \& Al-Muhaysin, H. A. (2016). Effect of motivation by "Instagram" on adherence to physical activity among female college students. BioMed Research International, 2016 (February). https://doi.org/10.1155/2016/1546013

AlQahtani, N. A. (2018). The Effect of Social Networks on the Improvement of Saudi EFL Students. Journal of Humanities and Social Sciences, 2(8), 137-150. https://doi.org/10.4018/978-1-5225-1686-6.ch005

Azlan, N. A. B., Zakaria, S. B., \& Yunus, M. M. (2019). Integrative task-based learning: Developing speaking skill and increase motivation via Instagram. International Journal of Academic Research in Business and Social Sciences, 9(1), 620-636. https://doi.org/10.6007/ijarbss/v9-i1/5463

Boggiano, A. K., \& Pittman, T. S. (Eds.). (1992). Achievement and motivation: A socialdevelopmental perspective. Cambridge University Press.

Chen, H. (2011). Developing and evaluating an oral skills training website supported by automatic speech recognition technology. ReCALL, 23(1), 59-78. https://doi:10.1017/S0958344010000285

Devi, P., Virginia, B., \& Auli, M. (2020). The use of the social media Instragram in teaching EFL: effect on students' speaking ability. Proceeding of the 2nd International Conference on English Language Education (ICONELE) 2020, 1-14. 
Handayani, F. (2016). Instagram as a Teaching Tool? Really? Proceedings of the Fourth International Seminar on English Language and Teaching (ISELT-4) 2016, August, 320327.

Jalaludin, N. H., Awal, N. M., \& Abu, K. B. (2009). Linguistics and environment in English language learning: Towards the development of quality human capital. European Journal of Social Sciences, 9(4), 627-642.

Johns, K. (2015). Engaging and assessing students with technology: A review of Kahoot! The Delta Kappa Gamma Bulletin, 81, 89.

Khan, I. U., Ayaz, M., Khan, S., dan Khan, M. F. (2016). Effect of social media on enhancement of English learning proficiency at University Level in Khyber Pakhtunkhwa. Journal of Humanities and Social Sciences (IASET) Vol. 2, pp. 71-84.

Krashen, S. D. (1981). Second language acquisition and second language learning. Oxford: Pergamon Press.

Lin, C. H., Warschauer, M., \& Blake, R. (2016). Language learning through social networks: Perceptions and reality. Language Learning and Technology, 20(1), 124-147.

Lunden, I. (2020). Instagram is the fastest-growing social site globally, mobile devices rule over pcs for access human capital. Tech Crunch. Retrieved from https://techcrunch.com/2014/01/21/instagram-is-the-fastest-growing-social-site-

globally-mobile-devices-rule-over-pcs-for-social-access/

Manca, S., \& Ranieri, M. (2013). Is it a tool suitable for learning? A critical review of the literature on Facebook as a technology-enhanced learning environment. Journal of Computer Assisted Learning, 29(6), 487-504. https://doi.org/10.1111/jcal.12007

Mansor, N., \& Abd Rahim, N. (2017). Instagram in esl classroom. Man In India, 97(20), 107114.

Mat, S. S. C., \& Yunus, M. M. (2014). Attitudes and motivation towards learning english among FELDA school students. Australian Journal of Basic and Applied Sciences, 8(5), 1-8. http://ajbasweb.com/old/ajbas/2014/Special 2/1-8.pdf

McCarroll, N., \& Curran, K. (2013). Social networking in education. International Journal of Innovation in the Digital Economy, 4(1), 1-15. https://doi.org/10.4018/jide.2013010101

Obar, J. A., \& Wildman, S. (2015). Social media definition and the governance challenge: An introduction to the special issue. Telecommunications Policy, 39(9), 745-750. https://doi.org/10.1016/j.telpol.2015.07.014

Parveen, B. W. (2016). Use of technology in improving speaking skills. Journal of English Language and Literature (JOELL), 3(2).

Pratiwi, I. (2013). Improving the speaking skill through communicative activities of the eight grade students of MTs N 1 Mlati in the Academic Year of 2012/2013 (Master's thesis). Yogyakarta State University, Yogyakarta, Indonesia.

Pratiwi, M. F. (2013). The effectiveness of media instagram toward the students' speaking skills of tenth grade in SMAN 4 Malang. Journal of Chemical Information and Modeling, 53(9), 1689-1699.

Pujiati, H., Zahra, \& Tamela, E. (2019). The use of Instagram to increase students' motivation and students' competence in learning English. Proceedings of the 1st International Conference on Education Social Sciences and Humanities (ICESSHum 2019), 651-656. doi: https://doi.org/10.2991/icesshum-19.20 19.103

Robertson, A. (2019). Preparing for generation z: How cantTechnology enhanced learning be firmly embedded in our students' learning experience? A case study from Abertay University. INTED2019 Proceedings, 1(March), 5769-5773. 
https://doi.org/10.21125/inted.2019.1417

Simatupang, F. F., \& Salam, N. E. (n.d.). Fenomena selfie (self-portrait) di Instagram. Jom FISIP, 2(1), 1-15.

Sun, Y. C., \& Yang, F. Y. (2015) I help, therefore, I learn: service learning on Web 2.0 in an EFL speaking class, Computer Assisted Language Learning, 28:3, 202-219, DOI: 10.1080/09588221.2013.818555

Sun, Z., Lin, C.-H., You, J., jiao Shen, H., Qi, S., \& Luo, L. (2017). Improving the English-speaking skills of young learners through mobile social networking. Computer Assisted Language Learning, 30(3-4), 304-324. https://doi.org/10.1080/09588221.2017.1308384

Vivakaran, M. V., \& Neelamalar, M. (2018). Utilization of social media platforms for educational purposes among the faculty of higher education with special reference to Tamil Nadu. Higher Education for the Future, 5(1), 4-19. https://doi.org/10.1177/2347631117738638

Yen, Y. C., Hou, H. T., \& Chang, K. E. (2015). Applying role-playing strategy to enhance learners' writing and speaking skills in EFL courses using Facebook and Skype as learning tools: a case study in Taiwan. Computer Assisted Language Learning, 28(5), 383-406. https://doi.org/10.1080/09588221.2013.839568

Yunus, M. M., Hashim, H., Hashim, H. U., Yahya, Z. S., Sabri, F. S., Nazeri, A. N. (2019). Kahoot!: Engaging and active learning environment in ESL writing classrooms. International Journal of Innovation, Creativity and Change. 5(6), 141-152.

Zaki, A. A., \& Yunus, M. M. (2015). Potential of mobile learning in teaching of ESL academic writing. English Language Teaching, 8(6), 11-19. https://doi.org/10.5539/elt.v8n6p11 